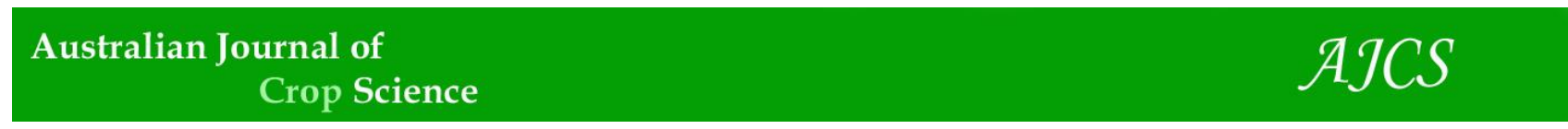

AJCS 10(9):1368-1374 (2016)

ISSN:1835-2707

DOI: 10.21475/ajcs.2016.10.09.p7892

\title{
Growth, yield and fruit quality of 'Maçã' banana under different rates of phosphorus fertilization
}

\author{
Ana Carolina Batista Bolfarini ${ }^{1 *}$, Sarita Leonel ${ }^{1}$, Magali Leonel ${ }^{2}$, Marco Antonio Tecchio ${ }^{1}$, Marcelo de \\ Souza Silva ${ }^{1}$, Jackson Mirellys Azevedo Souza ${ }^{1}$
}

${ }^{1}$ UNESP-São Paulo State University, Botucatu School of Agronomy (FCA/UNESP), Horticulture Department, Fruit Laboratory, Rua José Barbosa de Barros, CEP 18610-307, Botucatu, SP, Brazil

${ }^{2}$ UNESP-São Paulo State University, Center of Tropical Roots and Starches, Lageado Experimental Farm s/n, CEP 18610-307 Botucatu, SP, Brazil

*Corresponding author: anacarolinabolfarini@ hotmail.com

\begin{abstract}
The aim of this study was to evaluate the agronomic performance and fruit quality of 'Maçã' banana cultivar. A field experiment was conducted to study the effect of phosphorus $(\mathrm{P})$ on the cultivar. The study area presents a subtropical climate, where the mean temperature is $22^{\circ} \mathrm{C}$; and the mean rainfall is $1377 \mathrm{~mm}$. The experiment was conducted from November 2012 to May 2014 . The experiment design was totally randomized, consisting of six treatments $\left(0,40,60,80,100\right.$ and $120 \mathrm{~kg}_{2} \mathrm{O}_{5}$ ha $\left.{ }^{-1}\right)$ and seven repetitions. The results indicated that plant height, pseudo-stem diameter, number of live leaves, yield and fruit numbers per bunch increased at 51, 45, 44, 34 and $40 \mathrm{~kg} \mathrm{P}_{2} \mathrm{O}_{5}$ ha $^{-1}$, respectively. The shortest harvest cycle was of 480 days at $60 \mathrm{~kg} \mathrm{P}_{2} \mathrm{O}_{5} \mathrm{ha}^{-1}$. In unripe bananas, RSC improved $13 \%$ at $47 \mathrm{~kg} \mathrm{P}_{2} \mathrm{O}_{5}$ ha $^{-1}$; while the highest level of $\mathrm{P}, \mathrm{Ca}$ and $\mathrm{Mg}$ were obtained at 74, 41 and $58 \mathrm{~kg} \mathrm{P}_{2} \mathrm{O}_{5} \mathrm{ha}^{-1}$, respectively. During banana ripening, maximum fruit firmness $(3.07 \mathrm{~N})$ was achieved at $63 \mathrm{~kg} \mathrm{P}_{2} \mathrm{O}_{5}$ ha ${ }^{-1}$. Application of triple superphosphate fertilizer (at $34 \mathrm{~kg} \mathrm{P}_{2} \mathrm{O}_{5} \mathrm{ha}^{-1}$ ) increased yield, without changing physicochemical characteristics.
\end{abstract}

Keywords: Agronomic performance; physicochemical characteristics; mineral nutrition; Musa; triple superphosphate.

Abbreviations: Ca_Calcium; DM_Dry mass; MC_Moisture content; Mg_Magnesium; P_Phosphorus; RSC_Reducing sugar content; ST_Starch; SSC_Soluble solids content; TA_Titratable acidity; TSC_Total sugar content

\section{Introduction}

Bananas are among the world's most popular fruits and it is consolidated in the international market (Jaiswal et al., 2014). India is the world's largest producer. In 2013, India produced about 27.6 million tons of bananas. Brazil is the fourth largest producer (up from 6.89 million tons in 2013) (FAO, 2016). In Brazil, bananas had a great expansion due to the progress in strengthening all the supply chain, including fertilizer nutrients that are essential in meeting crop yield and fruit quality.

Phosphorus $(\mathrm{P})$ is an essential plant macronutrient, as it is a structural constituent of essential biomolecules involved in energy metabolism, such as ATP (Navaneethakrishnan and Kumar, 2013; Stigter and Plaxton, 2015). P converts solar energy into amino acids and fibre, besides that $\mathrm{P}$ promotes root growth and plant development. Thus, $\mathrm{P}$ is fundamental to nearly all major metabolic processes in plants, including photosynthesis and respiration.

According to Silva and Rodrigues (2013), who evaluated the first cycle of 'Dwarf-prata' banana, observed an increase in height, pseudo-stem diameter, bunch mass and number of fruits per bunch at different rates of $\mathrm{P}_{2} \mathrm{O}_{5}$. Al-Harthi and alYahyai (2009) evaluated growth and yield of 'Wiliams' banana under NPK fertilizer. They found that P (100 g plant ${ }^{-1}$ year $^{-1}$ ) increased bunch mass, hand mass and number of fruits per hands. These studies have suggested a need to adjust the phosphorus-based fertilizer recommendations for bananas. In São Paulo state, they recommend an application of 20-260 kg
$\mathrm{P}_{2} \mathrm{O}_{5} \mathrm{ha}^{-1}$, according to previous soil analysis and farmers' yield expectation (Teixeira et al., 1997).

In a study conducted in the North of Minas Gerais state (Brazil), Silva et al. (2007) found that the soils, where presented high productivity of banana, showed higher available $\mathrm{P}\left(39.2 \mathrm{mg} \mathrm{dm}^{-3}\right)$ compared to soils with low productivity of banana $\left(23 \mathrm{mg} \mathrm{dm}^{-3}\right)$. Moreover, Silva et al. (2011) found that depending on the type of the soil, where banana grows, $\mathrm{P}$ can be used more efficiently by plants, resulting in higher dry matter production, i.e. inferring a need of providing $\mathrm{P}$, when working with banana.

Regarding to the phosphate fertilizer on the root distribution system, by, it is important to consider that phosphate presents ions with low mobility; therefore, the more developed and extensive the roots are, the better $\mathrm{P}$ uptake. On the other hand, there are no studies on the effect of phosphorus on the banana starch synthesis. However, Zhao et al. (2015) studied the effect of $\mathrm{N}$ and $\mathrm{P}$ deficiency in transcription regulation of genes encoding key enzymes of the starch metabolism in duckweed (Landoltia punctata), they found that $\mathrm{P}$ deficiency caused a significant accumulation of starch. Thus, starch content increased from $8.86 \%$ (without treatment) to $23.0 \%$ (during P privation).

There is a huge interest on cultivating 'Maçã' banana, as its fruit composition, productive characteristics and economic importance are extremely susceptible. This cultivar can be hampered by wilt, i.e. "Panama disease" (Fusarium 
oxysporum f. sp./Foc), which limited the crop to only one productive cycle. Therefore, researching on fertilizer is viable and necessary; unlike other cultivars that generally require at least three productive crop cycles. Nutrients demand depends among cultivars and even within the same genomic group (Donato et al., 2010), while nutrient recommendations are mostly based on scientific data for 'Cavendish' varieties, as it is highly demanding variety. Banana absorbs less $\mathrm{P}$ than other macronutrients (Hoffmann et al., 2010). Consequently, there is little or no information in the literature on the effects of $\mathrm{P}$ fertilizers on banana crop, besides that Brazilian soil is generally very poor in available P. Therefore, it seems important to evaluate the agronomic performance and fruit quality of 'Maçã' banana under P fertilization.

\section{Results and Discussion}

\section{Plants development}

Regarding to the growth characteristics, there was a significant effect of triple superphosphate. It was also predicted a quadratic function on all adjustments. In biological terms, it means that soon after the inflection point, every increased unit of the applied fertilizer tends to decrease plant growth. Based on the equations, maximum plant height, pseudo-stem diameter and number of live leaves were of 51, 45 and $44 \mathrm{~kg} \mathrm{P}_{2} \mathrm{O}_{5} \mathrm{ha}^{-1}$, respectively (Fig $1 \mathrm{~A}, \mathrm{~B}$ and $\mathrm{C}$ ). The results corroborate the findings of Reis and Chepote (2008), who evaluated the effect of $P$ on 'Pacova' banana (AAB) in dystrophic red-yellow latosol (oxisoil), they also reported a quadratic function on plant height and pseudo-stem circumference. However, banana does not require large amounts of P (Silva and Rodrigues, 2013), phosphorus fertilization has proved to be necessary for growing 'Maçã' banana, which increases pseudo-stem diameter $(4.6 \%)$, but available $\mathrm{P}$ content tends to be extremely low in most latosols, because assimilable forms is restricted to a few plant (Silva et al., 2011). P can notably increase vegetative growth; being indispensable for cell division, as it is a constituent element of nucleoproteins (Malavolta, 1997). However, large amounts of $\mathrm{P}_{2} \mathrm{O}_{5}$ produce phytotoxic effects, such as inhibition of plant growth and reduction of photosynthetic activity (Marschner, 2005). This negative effect was observed on all evaluated characteristics, such as growth and production, from the inflection point (Fig 1, 2 and 3), when increased $\mathrm{P}$ level. Based on crop cycle characteristics, equations were generated. It was found that the maximum function point was of $61 \mathrm{~kg} \mathrm{P}_{2} \mathrm{O}_{5} \mathrm{ha}^{-1}$, when plants showed smaller interval in days from planting to flowering (367 days) (Fig 1D), whereas the lowest number of days (114 days) was of $53 \mathrm{~kg} \mathrm{P}_{2} \mathrm{O}_{5} \mathrm{ha}^{-1}$ from flowering to harvesting (Fig 1E). Regarding to the total cycle, the greatest plants precocity (480 days) has been observed at $60 \mathrm{~kg} \mathrm{P}_{2} \mathrm{O}_{5} \mathrm{ha}^{-1}$ (Fig 1F).

Therefore, plants precocity subjected to $\mathrm{P}_{2} \mathrm{O}_{5}$ doses, as it was mentioned above, are in line with the results reported by Silva et al. (2012), who stated that an adequate P supply ensures proper formation of reproductive organs and fruit growth. However, it is worth mentioning that high levels of $\mathrm{P}$ (i.e. above estimated dose) affect the length of the cycle and the availability of nutrients in the soil, i.e. any nutritional deficiency will hinder plant development.

\section{Plants agronomic performance}

The effect of increasing $\mathrm{P}_{2} \mathrm{O}_{5}$ doses on yield was accompanied by a form of quadratic function. The maximum function for bunch mass (Fig 2A) and yield (Fig 2F) was of
$34 \mathrm{~kg} \mathrm{P}_{2} \mathrm{O}_{5} \mathrm{ha}^{-1}$. Regarding to the greatest fruit mass (Fig 2C) and the largest number of hands per bunch (Fig 2E) were of 33 and $35 \mathrm{~kg} \mathrm{P}_{2} \mathrm{O}_{5} \mathrm{ha}^{-1}$, respectively. Therefore, it is clear that the maximum productive efficiency can be achieved at those levels of $\mathrm{P}_{2} \mathrm{O}_{5}$. On the other hand, rachis mass (Fig 2B) achieved its maximum function at $41 \mathrm{~kg} \mathrm{P}_{2} \mathrm{O}_{5} \mathrm{ha}^{-1}$, while the largest number of fruit per bunch (Fig 2D) was of $41 \mathrm{~kg} \mathrm{P}_{2} \mathrm{O}_{5}$ $\mathrm{ha}^{-1}$.

These findings corroborates with the one found by Liu et al. (2015), evaluating banana crop under fertilizations in China. The effect of increasing $\mathrm{P}$ doses was reported by a significant quadratic function on yield, but much higher levels. This fact was confirmed by Reis and Chepote (2008), reported quadratic effect of increasing $\mathrm{P}$ doses on 'Pacova' banana traits, such as bunch mass, hands mass and number of hands per bunch. Whether there is a proper use of fertilizers at a lower rate, it reduces the production final cost. However, it needs to be emphasized that the results reported above (i.e., higher doses) can be related to residual $\mathrm{P}$ in the soil and each cultivar demands. 'Maçã' banana has a low demand for P. In the soil, its initial $\mathrm{P}$ content $\left(16 \mathrm{mg} \mathrm{dm}^{-3}\right)$ was probably sufficient to the plant's needs; and root system development, because the mobility of phosphate ions is limited and apart from absorption, it is also related to the root length (Attia et al. 2009).

Regarding to the traits of the second hands of the bunch, which was verified by equations, the highest values were obtained for bunch mass, fruit number, length and diameter of the central five fruits at 41, 42, 42 and $40 \mathrm{~kg} \mathrm{P}_{2} \mathrm{O}_{5} \mathrm{ha}^{-1}$, respectively (Fig $3 \mathrm{~A}, \mathrm{~B}, \mathrm{C}$ and $\mathrm{D}$ ). Results noted that supplying $\mathrm{P}$ to the maximum function point (i.e. at $34 \mathrm{~kg}$ $\left.\mathrm{P}_{2} \mathrm{O}_{5} \mathrm{ha}^{-1}\right)$ increased the yield $\left(11.92 \mathrm{t} \mathrm{ha}^{-1}\right)$ (Fig 2F). It is noteworthy that the estimated dose in this study is higher than the recommended for the crop, corresponding to $20 \mathrm{~kg} \mathrm{P}_{2} \mathrm{O}_{5}$ ha $^{-1}$ (Teixeira et al., 1997). This result emphasizes the importance of this kind of study, since the use of appropriate doses for each cultivar result in higher production and financial return. However, the lower performance in the maximum function can be explained by the high concentration of salt in the soil due to the high concentrations of phosphate fertilizer, which may be toxic to the plants and according to Oliveira et al. (2006) it reduces root growth, i.e. affecting nutrients absorption.

\section{Physicochemical aspects of banana fruits}

There was no significant difference of $\mathrm{P}$ on moisture content (MC); dry mass (DM); total sugar content (TSC); starch (ST); and micronutrients in unripe fruits. There was also no significant difference in fruit peel colour parameters; $\mathrm{pH}$; SSC (soluble solids content); TA (titratable acidity); ratio; and RSC (reducing sugar content) in ripened fruits (Table 1). Absorbing small amounts of elements appears to have little influence compared to nutrients demand for all major parts of banana. Thus, micronutrients content have not responded to the $\mathrm{P}$ fertilization. RSC increases during ripening as a result of starch hydrolysis. However, low starch deposition resulted in similar levels of RSC among the treatments, in terms of $\mathrm{P}_{2} \mathrm{O}_{5}$ doses. Fruit peel colour; $\mathrm{pH}$; $\mathrm{SSC}$; TA; malic acid; and ratio found to be similar to those described in the literature for the same cultivar (Pinheiro et al., 2007).

There was a significant effect of $\mathrm{P}$ on RSC in unripe fruits. The highest value was of $47 \mathrm{~kg} \mathrm{P}_{2} \mathrm{O}_{5} \mathrm{ha}^{-1}$ (Fig 4). Higher doses of $\mathrm{P}$ reduce sugars deposition in fruit, causing toxicity, impairing roots function and reducing essential nutrients uptake; according to Marschner (2005), high P concentrations tend to reduce photosynthetic process. 
Table 1. Mean values of moisture content, dry mass, total sugar content, starch and micronutrients in unripe fruits; and mean brightness values $(\mathrm{L}), * \mathrm{a}$ e *b coordinates, $\mathrm{pH}$, soluble solids content, titratable acidity, ratio (SS/TA) and reducing sugar in ripened fruits of 'Maçã' banana, fertilized with $\mathrm{P}_{2} \mathrm{O}_{5}$ in kg ha ${ }^{-1}$. Botucatu School of Agronomy UNESP, São Manuel, SP, 2015.

\begin{tabular}{|c|c|c|c|c|c|c|c|c|c|}
\hline \multirow[b]{2}{*}{$\begin{array}{l}\text { Dose of } \mathrm{P}_{2} \mathrm{O}_{5} \\
\left(\mathrm{~kg} \mathrm{ha}^{-1}\right)\end{array}$} & \multicolumn{9}{|c|}{ Unripe fruits } \\
\hline & $\mathrm{MC}$ & $\begin{array}{c}\text { DS } \\
--\mathrm{g} 100 \mathrm{~g}^{-}\end{array}$ & 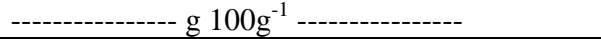 & ST & \multicolumn{4}{|c|}{ 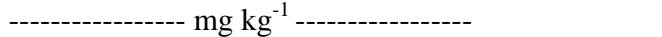 } & $\mathrm{Zn}$ \\
\hline 0 & 61.93 & 38.07 & 0.65 & 21.89 & 6.98 & 4.00 & 17.30 & 13.33 & 5.60 \\
\hline 40 & 61.78 & 38.22 & 0.72 & 22.02 & 7.07 & 4.50 & 18.10 & 15.33 & 5.80 \\
\hline 60 & 61.82 & 38.18 & 0.78 & 21.91 & 7.29 & 4.50 & 18.00 & 14.67 & 6.00 \\
\hline 80 & 62.11 & 37.89 & 0.69 & 21.53 & 7.16 & 4.25 & 16.20 & 13.92 & 5.40 \\
\hline 100 & 62.24 & 37.76 & 0.63 & 21.44 & 7.07 & 4.00 & 16.35 & 14.50 & 5.40 \\
\hline 120 & 62.59 & 37.41 & 0.66 & 20.77 & 6.44 & 3.75 & 16.00 & 14.00 & 5.25 \\
\hline Effect & $\mathrm{NS}^{(1)}$ & NS & NS & NS & NS & NS & NS & NS & NS \\
\hline \multirow[t]{2}{*}{$\mathrm{CV}^{(2)}(\%)$} & 5.04 & 8.25 & 13.68 & 10.03 & 9.94 & 17.44 & 12.98 & 14.71 & 9.79 \\
\hline & \multicolumn{9}{|c|}{ Ripened fruits } \\
\hline \multirow{2}{*}{$\begin{array}{l}\text { Dose of } \mathrm{P}_{2} \mathrm{O}_{5} \\
\left(\mathrm{~kg} \mathrm{ha}^{-1}\right)\end{array}$} & \multirow{2}{*}{\multicolumn{3}{|c|}{ Fruit peel colour }} & \multirow{2}{*}{$\mathrm{pH}$} & SSC & \multirow{2}{*}{\multicolumn{2}{|c|}{$\begin{array}{l}\text { TA } \\
\left(\mathrm{g} 100 \mathrm{~g}^{-1}\right)\end{array}$}} & \multirow{2}{*}{$\begin{array}{l}\text { Ratio } \\
\text { (SS/TA) }\end{array}$} & \multirow{2}{*}{$\begin{array}{l}\text { RSC } \\
(\%)\end{array}$} \\
\hline & & & & & $\left({ }^{\circ}\right.$ Brix $)$ & & & & \\
\hline 0 & 69.97 & 4.10 & 46.18 & 4.37 & 23.60 & 0. & & 46.68 & 16.88 \\
\hline 40 & 70.67 & 4.74 & 47.85 & 4.38 & 23.88 & 0. & & 47.70 & 17.09 \\
\hline 60 & 70.92 & 4.14 & 47.73 & 4.40 & 24.00 & 0. & & 50.02 & 17.13 \\
\hline 80 & 70.41 & 3.91 & 47.58 & 4.35 & 23.56 & 0. & & 45.66 & 16.79 \\
\hline 100 & 68.79 & 3.94 & 47.28 & 4.38 & 23.48 & 0. & & 44.24 & 16.70 \\
\hline 120 & 68.68 & 4.12 & 47.35 & 4.33 & 23.42 & 0.5 & & 43.93 & 16.65 \\
\hline Effect & NS & NS & NS & NS & NS & $\mathrm{Ns}$ & & NS & NS \\
\hline $\mathrm{CV}(\%)$ & 3.05 & 14.38 & 8.92 & 0.98 & 3.54 & 7.0 & & 9.46 & 7.34 \\
\hline
\end{tabular}

${ }^{(1)}$ No significant by Tukey test at $5 \%$ probability. ${ }^{(2)}$ Coefficient of variation.

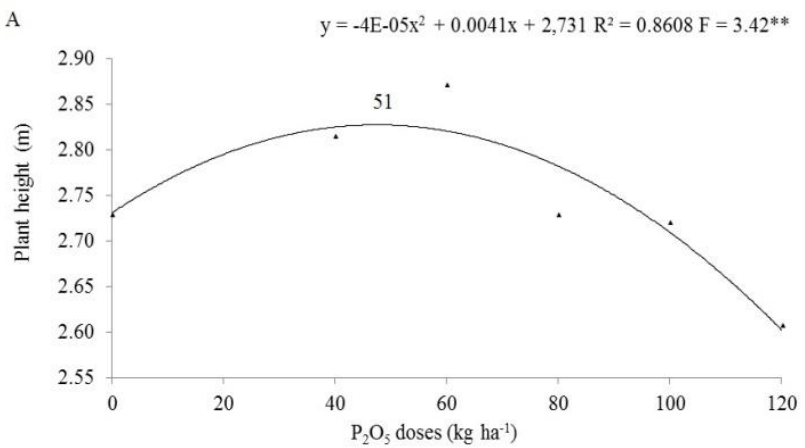

C
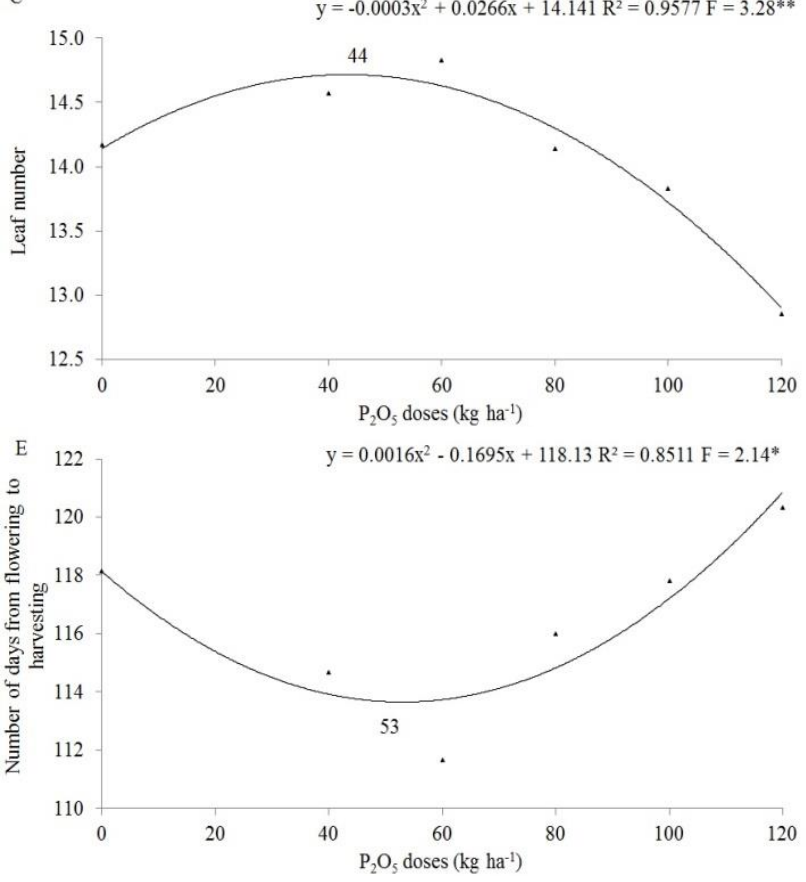
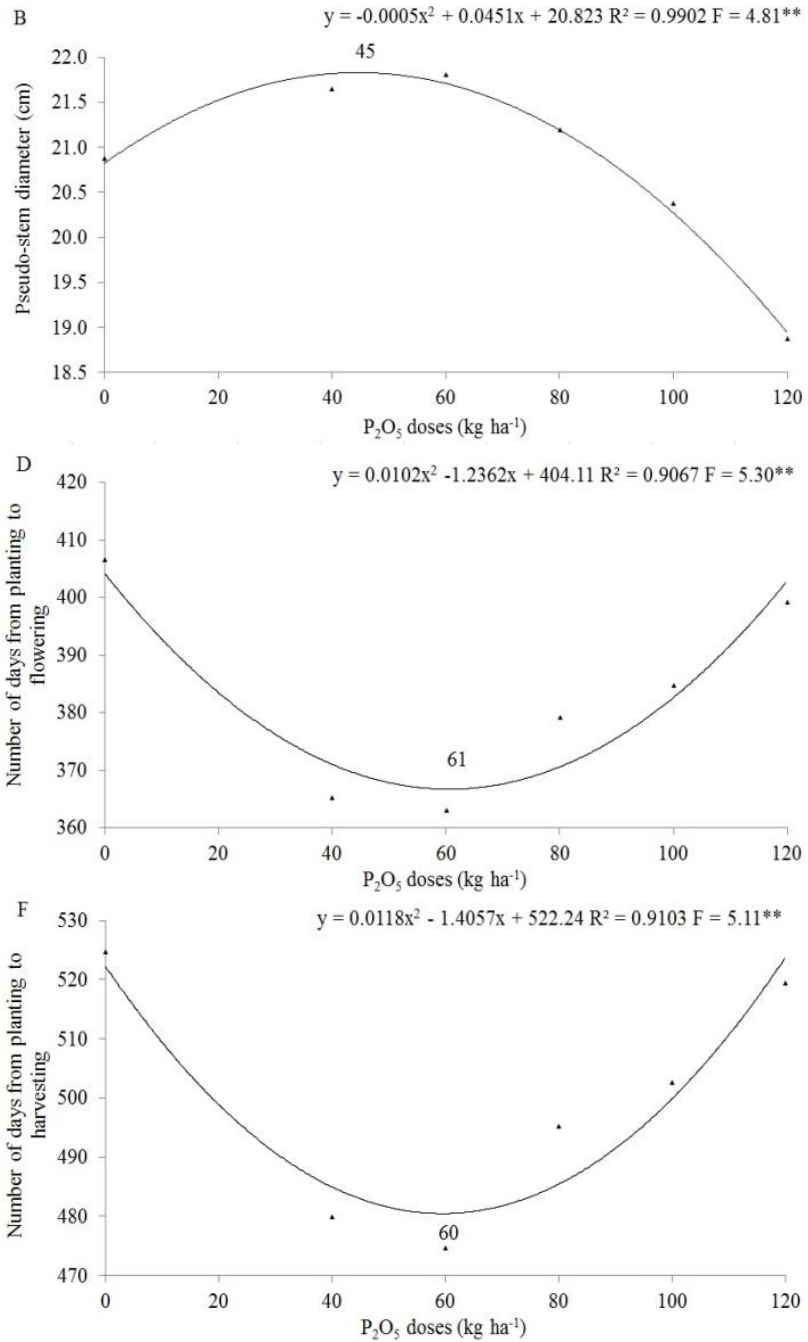

Fig 1. Plant height $(\mathrm{m})(\mathrm{A})$, pseudo-stem diameter $(\mathrm{cm})(\mathrm{B})$, leaf number $(\mathrm{C})$, number of days from: planting to flowering (D), flowering to harvesting (E) planting to harvesting (crop cycle) (F) of 'Maçã' banana, fertilized with $\mathrm{P}_{2} \mathrm{O}_{5}$ in $\mathrm{kg}$ ha' . Botucatu School of Agronomy UNESP, São Manuel, SP, 2015. **Significant at 1\% probability and * Significant at 5\% probability. 

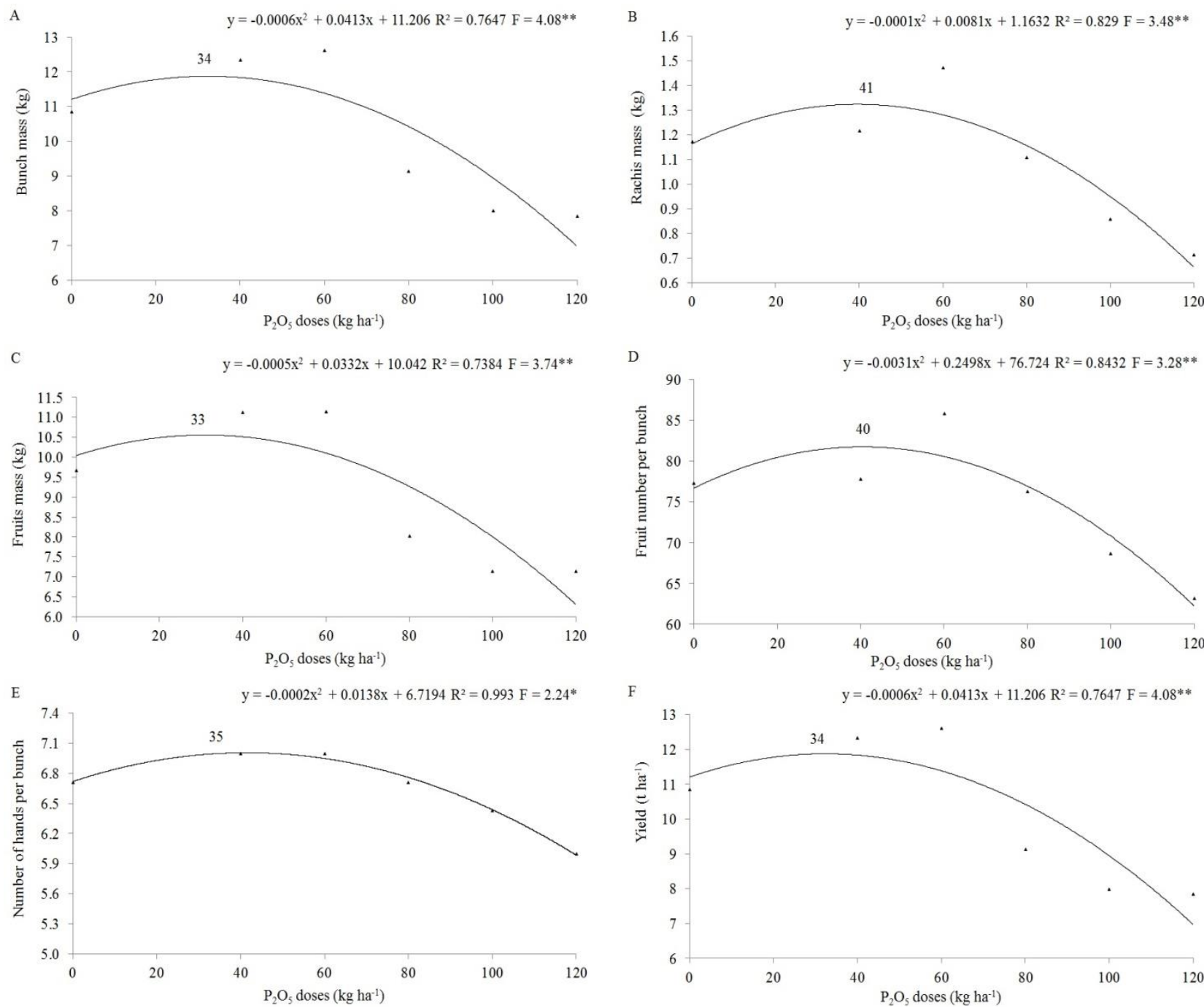

Fig 2. Bunch mass (A), Rachis mass (B), Fruits mass (C), Fruit number per bunch (D), Number of hands per bunch (E) and yield (F) of 'Maçã' banana, fertilized with $\mathrm{P}_{2} \mathrm{O}_{5}$ in $\mathrm{kg} \mathrm{ha}^{-1}$. Botucatu School of Agronomy UNESP, São Manuel, SP, 2015. **Significant at $1 \%$ probability and $*$ Significant at $5 \%$ probability.

Firmness was significantly affected by $\mathrm{P}$ fertilization in ripe fruits. The maximum value was of $63 \mathrm{~kg} \mathrm{P}_{2} \mathrm{O}_{5}$ ha $^{-1}$ (Fig 5). This has suggested that increasing calcium $(\mathrm{Ca})$ by using $\mathrm{P}$, contributed to increase fruit firmness.

Regarding to the macronutrients content, there was a significant effect of $\mathrm{P}_{2} \mathrm{O}_{5}$ for $\mathrm{P}$; $\mathrm{Ca}$; and $\mathrm{Mg}$ (Fig 6) in unripe fruits. The mean values for $\mathrm{N} ; \mathrm{K}$ and $\mathrm{S}$ content were of 6.04 , 10.67 and $0.97 \mathrm{mg} \mathrm{kg}^{-1}$, respectively. Triple superphosphate increased $\mathrm{P}$ uptake, causing a quadratic effect. The maximum value of $\mathrm{P}$ was of $74 \mathrm{~kg} \mathrm{P}_{2} \mathrm{O}_{5}$ ha $^{-1}$ (Fig 6A). The highest value of $\mathrm{Ca}$ was of $41 \mathrm{~kg} \mathrm{P}_{2} \mathrm{O}_{5} \mathrm{ha}^{-1}$ (Fig 6B), while the maximum value of $\mathrm{Mg}$ was of $58 \mathrm{~kg} \mathrm{ha}^{-1}$ (Fig 6C). However, it was observed a side effect, as the fruits presented more macronutrients than needed, which damaged the root system by impairing its absorption, as reported by Oliveira et al. (2006).

By applying triple superphosphate, the soil available $\mathrm{P}$ increased linearly (Fig 7), but leaf P content did not alter, with a mean of $1.58 \mathrm{~g} \mathrm{~kg}^{-1}$. The result corroborates the findings of Silva and Rodrigues (2013), evaluated 'Dwarfprata' banana in four production cycles and reported that the third leaf from the apex, which is commonly used for nutrient content analysis, may not be sensitive to detect $\mathrm{P}$ deficiency or excess.

\section{Materials and Methods}

\section{Location and soil classification}

The fruit were harvested in the São Manuel Experimental Farm, Botucatu School of Agronomy, UNESP (22 44 '28"S, $48^{\circ} 34^{\prime} 37^{\prime \prime} \mathrm{W} ; 740 \mathrm{~m} \mathrm{~m}$ altitude; climate type Cfa, according to Köppen's classification). The mean annual rainfall of São Manuel is $1377 \mathrm{~mm}$; and the mean annual temperature is $22^{\circ} \mathrm{C}$. The soil is classified as Dystrophic Red Latosol (Oxisoil). The experiment was conducted from November 2012 to May 2014, when it was evaluated the first productive cycle of 'Maçã' banana in dryland cropping system.

Soil samples were collected at a depth of $0-20 \mathrm{~cm}$ to determine their chemical properties: $\mathrm{pH}$ in $\mathrm{CaCl}_{2}, 5.5$; M.O., $12 \mathrm{~g} \mathrm{dm}^{-3}$; Presin, $16 \mathrm{mg} \mathrm{dm}^{-3} ; \mathrm{H}+\mathrm{Al}, 15 \mathrm{mmol}_{\mathrm{c}} \mathrm{dm}^{-3} ; \mathrm{K}, 1$ $\mathrm{mmol}_{\mathrm{c}} \mathrm{dm}^{-3}$; Ca, $13 \mathrm{mmol}_{\mathrm{c}} \mathrm{dm}^{-3} ; \mathrm{Mg}, 5 \mathrm{mmol}_{\mathrm{c}} \mathrm{dm}^{-3} ; \mathrm{SB}, 19$ $\mathrm{mmol}_{\mathrm{c}} \mathrm{dm}^{-3}$; CTC, $34 \mathrm{mmolc} \mathrm{dm}^{-3}$; V\%, 57; S, $1 \mathrm{mg} \mathrm{dm}^{-3}$. 

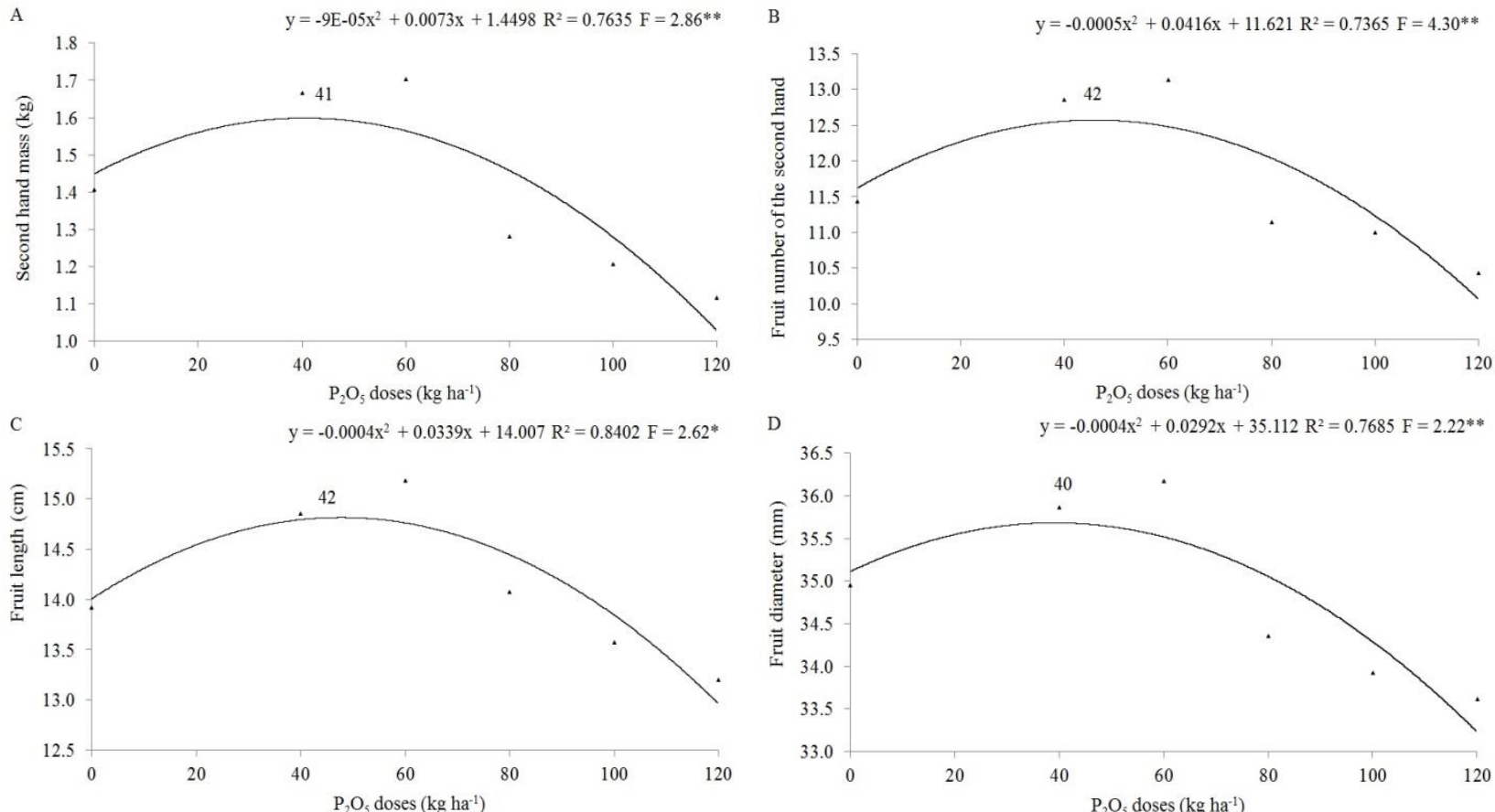

Fig 3. Second hand mass (A), Fruit number of the second hand (B), Fruit length (C) e Fruit diameter (D) of 'Maçã' banana, fertilized with $\mathrm{P}_{2} \mathrm{O}_{5}$ in $\mathrm{kg} \mathrm{ha}^{-1}$. Botucatu School of Agronomy UNESP, São Manuel, SP, 2015. **Significant at $1 \%$ probability and *Significant at $5 \%$ probability.

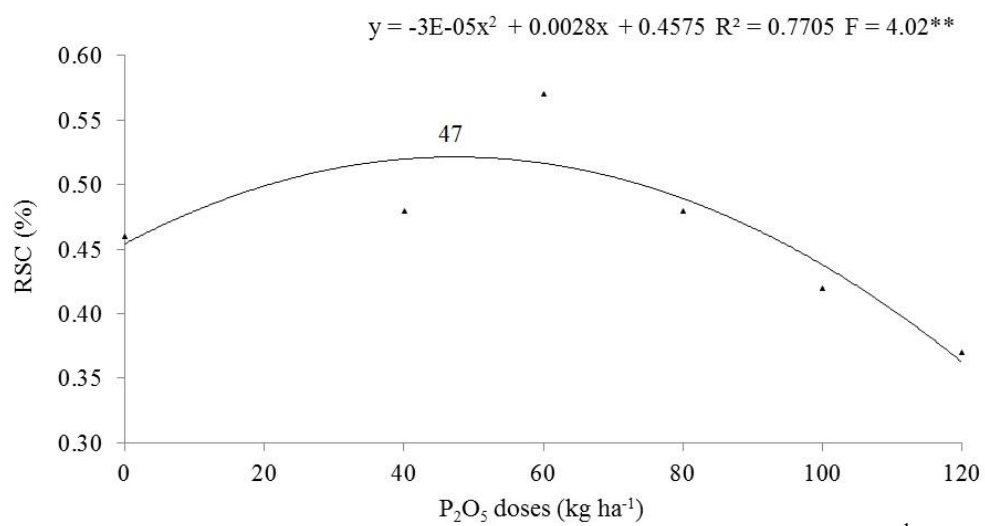

Fig 4. Reducing sugar content in unripe fruits of 'Maçã' banana, fertilized with $\mathrm{P}_{2} \mathrm{O}_{5}$ in $\mathrm{kg}^{-1}$. Botucatu School of Agronomy UNESP, São Manuel, SP, 2015. ** Significant at $1 \%$ probability.

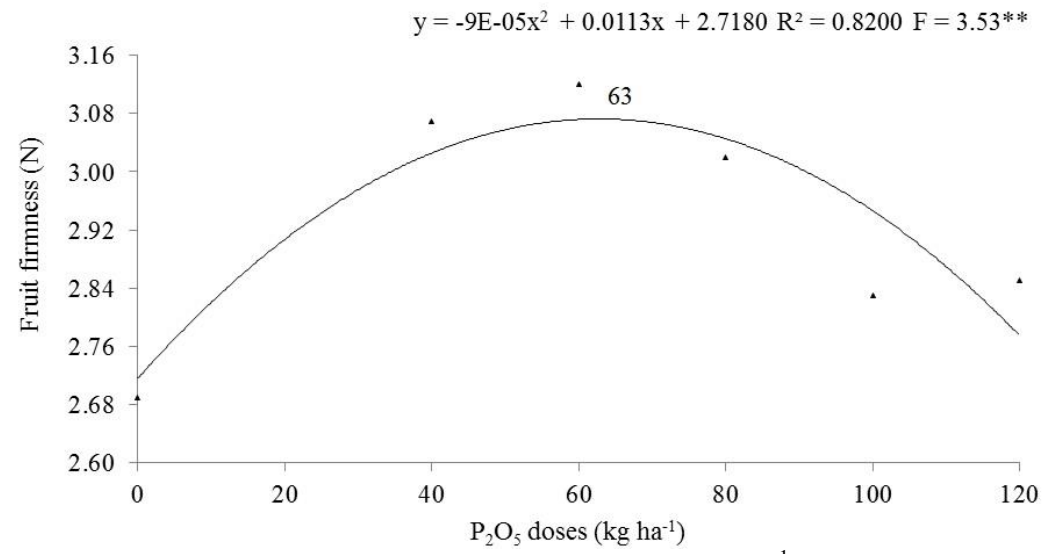

Fig 5. Fruit firmness in ripened fruits of 'Maçã' banana, fertilized with $\mathrm{P}_{2} \mathrm{O}_{5}$ in kg ha ${ }^{-1}$. Botucatu School of Agronomy UNESP, São Manuel, SP, 2015. ** Significant at $1 \%$ probability. 

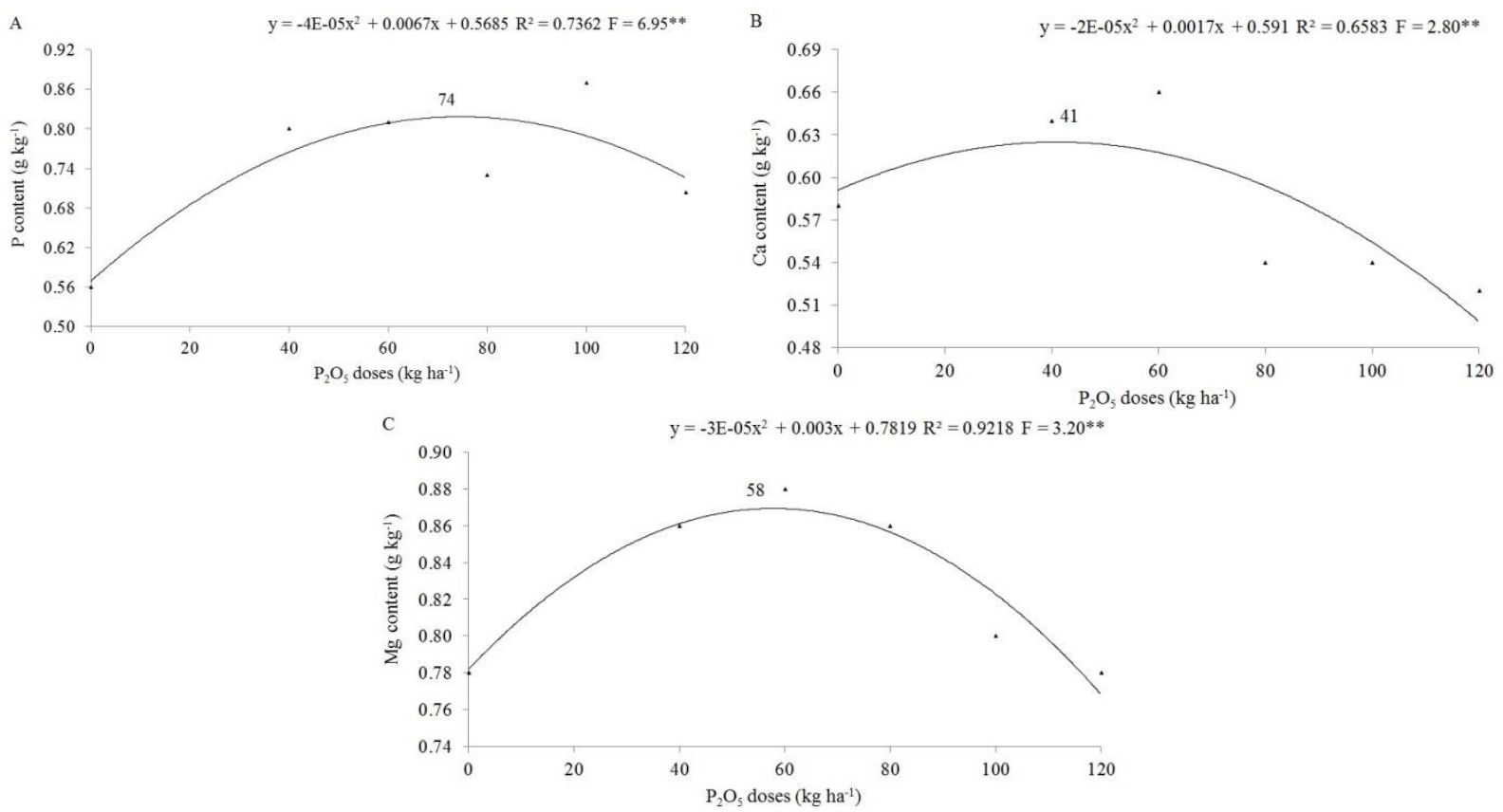

Fig 6. Phosphorus (E), calcium (B) and magnesium (C) content on dry mass in unripe fruits of 'Maçã' banana, fertilized with $\mathrm{P}_{2} \mathrm{O}_{5}$ in $\mathrm{kg} \mathrm{ha}^{-1}$. Botucatu School of Agronomy UNESP, São Manuel, SP, 2015. ** Significant at 1\% probability.

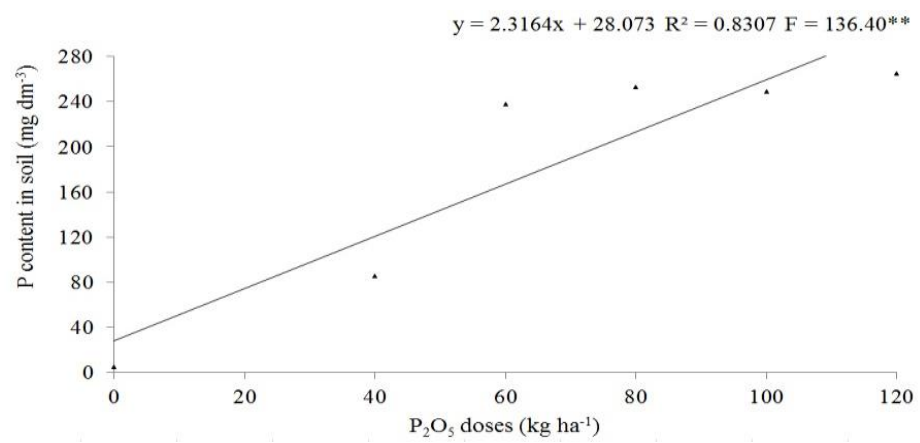

Fig 7. Available phosphorus content in soil cultivated with 'Maçã' banana fertilized with $\mathrm{P}_{2} \mathrm{O}_{5}$ in $\mathrm{kg}$ ha ${ }^{-1}$. Botucatu School of Agronomy UNESP, São Manuel, SP, 2015. ** Significant at 1\% probability.

\section{Plant materials and experimental design}

In November 2012, micropropagated 'Maçã' banana plantlets $(\mathrm{AAB})$ were transplanted with a spacing of $4 \mathrm{~m}$ between rows and $2.5 \mathrm{~m}$ between the plants, totalling $1000 \mathrm{ha}^{-1}$ plant. The experiment design was totally randomized, consisting of 6 doses of triple superphosphate $(0,40,60,80,100$ and $120 \mathrm{~kg}$ $\mathrm{P}_{2} \mathrm{O}_{5} \mathrm{ha}^{-1}$ ) and 7 repetitions. $\mathrm{P}$ fertilizer was applied twice: half of the six doses were applied into the planting hole; and at 80 days after planting, the other half was applied within a radius of $100 \mathrm{~cm}$ around the plants. The doses were defined according to the method described by Teixeira et al. (1997), with respect to initial available $P$ content in the soil $(16 \mathrm{mg}$ $\left.\mathrm{dm}^{-3}\right)$; and expected yield for the first cycle $\left(<20 \mathrm{t} \mathrm{ha}^{-1}\right)$.

During inflorescence phase, it was collected leaf samples (Teixeira et al., 1997); and $\mathrm{P}$ levels were evaluated (Malavolta et al., 1997). At the end of harvest, the resin method was used to measure the quantity of potentially available $\mathrm{P}$ by collecting four simple soil samples per plot (at a depth of $0-20 \mathrm{~cm}$ ) in the fertilization area, which formed a composite sample (Silva and Rodrigues, 2013).

\section{Plants development and agronomic performance}

The plants development characteristics were: plant height, pseudo-stem diameter and number of live leaves, which were all measured at the inflorescence appearance. The plant cycle was determined in days from planting to flowering; from flowering to harvesting; and from planting to harvesting. The agronomic performance analyses were: bunch mass; fruit mass; rachis mass; number of fruits per bunch; yield; and number of hands per bunch. The physical analyses were: mass; fruit number; length and diameter of the five central fruits of second hand of the bunch.

\section{Physicochemical aspects of banana fruits}

The physicochemical analysis determined fruit quality. The process was carried out in unripe and ripened fruit by using five bunches per treatment. In unripe fruits, it was randomly selected twelve fruits during ripening stage 1 (totally green peel), according to Von Loesecke (Leonel et al, 2011.). After dehydration, the analyses were: MC, DM, TSC and RSC, starch, macro and micronutrients (Somogy-Nelson, 1944; 
Malavolta et al., 1997; AOAC, 2005). When the fruits of the second hand reached maturity at stage 6 (fruit peel colour: $100 \%$ yellow), firmness was determined in a texture meter (TA.XTplus Texture Analyzer), with a penetration depth of $2.0 \mathrm{~mm} \mathrm{~s}^{-1}$; fruit peel colour (with a Minolta CR-300 colorimeter); $\mathrm{pH}$; TA (expressed in grams of malic acid 100 $\mathrm{g}^{-1}$ pulp); SSC (AOAC, 2005); ratio (SS/TA); and RSC.

\section{Statistical analysis}

Data were subjected to analysis of regression using the statistical Sisvar software (Ufla, Lavras, MG, Brazil) and graphical representations were made with Excel. Differences between means were subjected to analysis of variance by $\mathrm{F}$ test, and compared by Tukey test at $5 \%$ probability.

\section{Conclusion}

The evaluated cultivar presented better growing conditions; cycle length; and productive performance at 33-61 $\mathrm{kg} \mathrm{P}_{2} \mathrm{O}_{5}$ $\mathrm{ha}^{-1}$. Fruit quality is not affected by $\mathrm{P}$ fertilization, except of RSC (at $47 \mathrm{~kg} \mathrm{P}_{2} \mathrm{O}_{5} \mathrm{ha}^{-1}$ ) in unripe fruits; and firmness (at 63 $\left.\mathrm{kg} \mathrm{P}_{2} \mathrm{O}_{5} \mathrm{ha}^{-1}\right)$ in ripe fruits. The use of $\mathrm{P}$ on soil did not change any micronutrients levels in unripe fruit; but it provided higher quantitative values for $\mathrm{P}$; $\mathrm{Ca}$ and $\mathrm{Mg}$ at 74 , 41 and $58 \mathrm{~kg} \mathrm{P}_{2} \mathrm{O}_{5}$ ha $^{-1}$.

\section{Acknowledgements}

The authors would thank to the Coordination for the Improvement of Higher Education Personnel (CAPES) to scholarship granted for the master's degree studies of the first author.

\section{References}

Al-Harthi K, Al-Yahyai R (2009) Effect of NPK fertilizer on growth and yield of banana in northern Oman. J Hortic For. $1(8): 160-167$.

AOAC (2005) Official methods of analysis of the association of oficial analitycal chemistry international. 18th edh.1015p.

Attia M, Ahmed MA, El-Sonbaty MR (2009) Use of biotechnologies to increase growth, productivity and fruit quality of 'Maghrabi' banana under different rates of phosphorus. World J Agric Sci. 5(2):211-220.

Donato SLR, Lédo AA, Pereira MCT, Coelho EF, Cotrim CE (2010) Estado nutricional de bananeiras tipo 'Prata' sob diferentes sistemas de irrigação. Pesqui Agropecu Bras. 45(9): $980-988$

FAO. Food and Agricultural Organization, 2013. Availabe in: <http://faostat3.fao.org/browse/Q/QC/E>, accessed in 2016 January.

Hoffmann RB, Oliveira FHT, Souza AP, Gheyi HR, Souza Júnior RF (2010) Acúmulo de matéria seca e de macronutrientes em cultivares de bananeira irrigada. Rev Bras Frutic. 32(1):268-275.

Jaiswal P, Jha SN, Kaur PP, Bhardwaj R, Singh AK, Wadhawan V (2014) Prediction of textural attributes using color values of banana (Musa sapientum) during ripening. J Food Sci Technol. 51(6):1179-1184.

Leonel M, Carmo EL, Leonel S, Franco CML, Campanha CB (2011) Extração e caracterização do amido de diferentes genótipos de bananeira. Rev Bras Frutic. 33:599-605.

Liu Y, Jing T, Tang F, Zang X, Zheng W, Cao H, Ju J, Wang B, Li C (2015) Studies on the fertilization effect and optimal fertilizing amount of Brazil banana based on “3414” field trials. Agric Sci Tech. 16(9):1950-1954.

Malavolta E, Vitti GC, Oliveira AS (1997) Avaliação do estado nutricional das plantas: princípios e aplicações. 2 edh. 319p.

Marschner H (2005) Mineral nutrition of higher plants. 6th ed. $889 \mathrm{p}$.

Navaneethakrishnan KS, Gill MIS, Kumar SR (2013) Effect of different levels of $\mathrm{N}$ and $\mathrm{P}$ on ratoon banana (Musa spp. AAA). J Hortic For. 5(6):81-91.

Nelson NA (1944) A photometric adaptation of Somogyi method for the determination of glucose. J Biol Chem. 15:375-80.

Oliveira AP, Silva JEL, Pereira, WE, Barbosa LJN, Oliveira AN (2006) Características produtivas da batata-doce em função de doses de $\mathrm{P}_{2} \mathrm{O}_{5}$, de espaçamentos e de sistemas de plantio. Cienc Agrotec. 30(4):611-617.

Pinheiro ACM, Vilas Boas EVB, Alves AP, La Selva M (2007) Amadurecimento de bananas 'Maçã' submetidas ao 1-metilciclopropeno (1-mcp). Rev Bras Frutic. 29(1):1-4.

Reis EL, Chepote RE (2008) Efeito do nitrogênio, fósforo e potássio no desenvolvimento e produção da bananeira no sul da Bahia. Agrotrópica. 20(5):3-20.

Silva JTA, Pacheco DD, Costa EL (2007) Atributos químicos e físicos de solos cultivados com bananeira 'Prata-Anã' (AAB), em três níveis de produtividade, no norte de Minas Gerais. Rev Bras Frutic. 29(1):102-106.

Silva JTA, Rodrigues MGV (2013) Produção da bananeira 'Prata Anã' em função da aplicação de adubo fosfatado, em quatro ciclos. Pesqui Agropecu Bras. 48(6):613-618.

Silva JTA, Silva IP, Pereira RD (2011) Adubação fosfatada em mudas de bananeira 'Prata Anã' (AAB), cultivadas em dois latossolos. Rev Ceres. 58(1):238-242.

Silva TR, Menezes JFS, Assis RL (2012) Desenvolvimento inicial do milho e disponibilidade de $\mathrm{P}$ sob adubação com raspa de vala da suinocultura. Enci Bios. 8(14):358-368.

Stigter KA, Plaxton WC (2015) Molecular mechanisms of phosphorus metabolism and transport during leaf senescence. Plants. 4(4):773-798.

Teixeira LAJ, Spironello A, Quaggio JA, Furlani PR (1997) Banana. In: Raij BV, Cantarella H, Quaggio JÁ, Furlani AMC (Ed.). Recomendações de adubação e calagem para o estado de São Paulo.131-132.

Zhao Z, Shi H, Wang M, Cui L, Zhao H, Zhao Y (2015) Effect of nitrogen and phosphorus deficiency on transcription al regulation of genes encoding key enzymes of starch metabolism in duckweed (Landoltia punctata). Plant Physiol Bioch. 86:72-81. 